\title{
PERANAN MOTIVASI KERJA, KOMITMEN ORGANISASI DAN BUDAYA ORGANISASI TERHADAP KEPUASAN KERJA
}

\author{
Oleh : Didit Darmawan
}

\begin{abstract}
This study aims to analyze and determine the effect of work motivation, organizational commitment and organizational culture have a significant influence partially and simultaneously to the satisfaction of elementary school teachers in School Cluster VI Kejayan District Pasuruan District. This research was conducted by involving 45 respondents and using multiple linear regression analysis. The regression equation is $Y=7,967+0,244 X 1+0,262 X 2+0,143 X 3$. The findings of the research show several findings, namely (1) work motivation, organizational commitment, and organizational culture have a significant influence simultaneously on the satisfaction of teachers of elementary school in school cluster VI Kejayan sub-district Pasuruan regency; (2) work motivation, organizational commitment, and organizational culture have a partially significant influence on the satisfaction of elementary school teachers in school cluster VI Kejayan sub-district Pasuruan Regency; (3) work motivation proved to have a dominant influence significantly on the work satisfaction of elementary school teachers in school cluster VI Kejayan sub-district Pasuruan regency.
\end{abstract}

Keywords: motivation, organizational commitment, organizational culture, and job satisfaction

\begin{abstract}
ABSTRAK
Penelitian ini bertujuan untuk menganalisis dan mengetahui pengaruh motivasi kerja, komitmen organisasi dan budaya organisasi berpengaruh signifikan secara parsial dan secara simultan terhadap kepuasan kerja guru SD di Gugus Sekolah VI Kecamatan Kejayan Kabupaten Pasuruan. Penelitian ini dilakukan dengan melibatkan 45 responden dan menggunakan analisis regresi linier berganda. Adapun persamaan regresinya adalah $Y=7,967+0,244 X 1+0,262 X 2$ $+0,143 X 3$. Dari temuan penelitian menunjukkan beberapa temuan, yaitu (1) motivasi kerja, komitmen organisasi, dan budaya organisasi mempunyai pengaruh yang signifikan secara simultan terhadap kepuasan kerja guru SD di Gugus Sekolah VI Kecamatan Kejayan Kabupaten Pasuruan; (2) motivasi kerja, komitmen organisasi, dan budaya organisasi mempunyai pengaruh yang signifikan secara parsial terhadap kepuasan kerja guru SD di Gugus Sekolah VI Kecamatan Kejayan Kabupaten Pasuruan; (3) motivasi kerja terbukti berpengaruh dominan secara signifikan terhadap kepuasan kerja guru SD di Gugus Sekolah VI Kecamatan Kejayan Kabupaten Pasuruan.
\end{abstract}

Kata-kata kunci: motivasi kerja, komitmen organisasi, budaya organisasi, dan kepuasan kerja. 


\section{PENDAHULUAN}

\section{Latar Belakang Masalah}

Saat ini pemerintah berusaha melakukan upaya pembenahan dan penyempurnaan peraturanperaturan sistem pendidikan sesuai kebutuhan dan perubahan. Hal ini tentu saja dilakukan sebagai wujud untuk memperbaiki kualitas dari sektor pendidikan secara keseluruhan melalui peningkatan produktivitas kerja para pelaku pendidikan seperti guru. Kemampuan profesional guru sebagai pondasi dasar dari proses belajar mengajar sangatlah penting untuk memperbaiki kualitas pendidikan yang menekankan pada perbaikan kualitas yang ada di setiap level pendidikan.

Meski demikian hal ini tidak mungkin akan tercapai jika tidak disertai usaha paraguru untuk senantiasa meningkatkan kemampuan profesionalnya untuk melaksanakan tugasnya sebagai pengajar. Kewajiban guru untuk meningkatkan kemampuan profesionalnya tidak hanya berguna bagi dirinya, namun memiliki arti yang baik bagi upaya pengembangan kualitas pendidikan pada umumnya. Usaha apapun yang dilakukan di bidang pendidikan adalah untuk mewujudkan tujuan pendidikan nasional, yaitu mengembangkan kemampuan danmembentuk karakter serta peradaban bangsa yang memiliki martabat serta untuk mencerdaskan kehidupan bangsa. Pendidikan nasional akan mampu membentuk manusia-manusia pembangunan yang mampu membentuk dirinya sendiri dan bersama-sama bertanggung jawab terhadap pembangunan bangsa.

Kemampuan profesional para guru ditingkatkan melalui pengembangan motivasi kerja. Motivasi kerja guru akan meningkat bila yang mereka merasa dipercaya, memperoleh pengakuan dari hasil kerjanya, mereka merasakan adanya keadilan di tempat kerja dan mendapatkan tantangan untuk menunjukkan kemampuannya. Di sisi lain, kebutuhan dari guru untuk memenuhi keinginannya semakin meningkat. Pada umumumnya guru bekerja dengan diawali harapan untuk mendapatkan imbalan berupa upah/gaji yang pantas untuk memenuhi kebutuhan mereka. Saat ini kebutuhan yang begitu kompleks dan kebutuhan manusia yang pada dasarnya tidak ada batasnya.Upaya yang ditunjukkan untuk memenuhi kebutuhan para guru dari kebutuhan fisik hingga kebutuhan aktulisasi diri untuk berprestasi berdasarkan prinsip objektivitas dan keadilan merupakan stimulus yang dapat memotivasi mereka dalam bekerja. Motivasi sebagai pendorong dan penggerak yang membentuk kegairahan dalam kerjaa individu sehingga mereka bersedia untuk bertindak untuk memenuhi beragam kebutuhannya untuk meraih kepuasaannya. Motivasi dari diri seseorang tersebut tidak lepas dari adanya aspek-aspek kebutuhan yang memicu seseorang untuk melakukan tindakan atau pekerjaan agar sampai pada hasil yang ingin dicapainya. Ketika seseorang telah mencapai pada hasil yang diinginkannya maka seseorang tersebut akan merasakan kepuasan kerja.

Untuk mengembangkan kualitas sumber daya manusia yang baik dalam organisasi, selain motivasi juga diperlukan komitmen guru terhadap organisasi. Hal ini diharapkan akan meningkatkan efektivitas dan efisiensi kerja, juga untuk mempercepat pemantapan perwujudan perilaku yang diinginkan organisasi terhadap guru. Hal ini sangat penting karena untuk mendukung upaya peningkatan kinerja guru yang berkualitas sehingga upaya tersebut akan mendukung pencapaian tujuan organisasi. Rendahnya komitmen menunjukkan kurang terpuaskan kebutuhan dan harapan guru pada keadaan organisasi sekolah yang kurang baik. Jika guru merasa kebutuhan dan harapannya terpenuhi tentu akan berusaha mempertahankan keanggotaannya, mengidentifikasi serta mengabdikan diri sepenuhnya pada sasaran dan tujuan organisasi sekolah sehingga komitmen guru terhadap organisasi sekolah akan tercipta dengan sendirinya. Dengan komitmen yang dimilikinya, guru akan dapat bekerja sepenuh hati, melibatkan diri secara aktif dan 
mengembangkan daya inovasi serta kreatifitas dalam kegiatan organisasi sekolah dan pada gilirannya akan tercipta prestasi kerja guru yang tinggi.

Setiap organisasi memilki budaya organisasi yang berfungsi untuk membentuk aturan atau pedoman dalam berfikir dan bertindak untuk mencapai tujuan yang ditetapkan. Hal ini berarti bahwa organisasi akan menuju perkembangan yang lebih baik bila budaya organisasi berkembang dengan baik. Meski demikian ada juga tekanan utama yang menyertai dalam perubahan dan upaya untuk mengembangkan budaya organisasi seperti adanya upaya untuk menghilangkan nilai-nilai, sikap dan perilaku dari anggota organisasi secara keseluruhan. Budaya organisasi menjadi konseptual secara sistematis yang menjadi pedoman tindakan atau perilaku kerja dalam rutinitas kerja dan menyebabkan para anggotanya bertindak terarah untuk mencapai tujuan organisasi. Kesepakatan yang terbentuk di budaya organisasi akan memudahkan terbentuknya kesepakatan di suatu organisasi yang lebih luas untuk kepentingan perorangan. Keutaman budaya organisasi merupakan pengendali dan arah dalam membentuk sikap dan perilaku manusia yang melibatkan diri dalam suatu kegiatan organisasi. Secara individu maupun kelompok seseorang tidak akan terlepas dengan budaya organisasi dan pada umumnya mereka akan dipengaruhi oleh keanekaragaman sumber-sumber daya yang ada sebagai stimulus seseorang bertindak. Dengan demikian budaya organisasi mempunyai peran yang sangat besar untuk mencapai tujuan organisasi. Budaya organisasi pada mulanya akan dipengaruhi oleh budaya sekitar dari para anggota organisasi. Budaya organisasi menunjukan kepribadian dari organisasi tersebut. Selain budaya organisasi, komunikasi juga memiliki peranan penting.

Sesuai dengan uraian pada latar belakang masalah, peneliti merasa tertarik untuk mengetahui dan menganalisa pengaruh variabel-variabel motivasi kerja, komitmen organisasi dan budaya organisasi terhadap kepuasan kerja guru. Dengan demikian judul penelitian ini adalah : "Pengaruh Kepemimpinan Kepala Sekolah, Komitmen dan Budaya Organisasi terhadap Kinerja Guru SD di Gugus Sekolah VI Kecamatan Kejayan Kabupaten Pasuruan.”

\section{Rumusan Masalah}

Berdasarkan latar belakang masalah yang diuraikan sebelumnya, maka permasalahan dalam penelitian ini dapat dirumuskan sebagai berikut : (1) apakah variabel motivasi kerja mempunyai pengaruh terhadap kepuasan kerja guru SD di Gugus Sekolah VI Kecamatan Kejayan Kabupaten Pasuruan? (2) apakah variabel komitmen organisasi mempunyai pengaruh terhadap kepuasan kerja guru SD di Gugus Sekolah VI Kecamatan Kejayan Kabupaten Pasuruan? (3) apakah variabel budaya organisasi mempunyai pengaruh terhadap kepuasan kerja guru SD di Gugus Sekolah VI Kecamatan Kejayan Kabupaten Pasuruan?

\section{KAJIAN TEORITIS}

Motivasi dinilai sebagai suatu daya dorong (driving force) yang menyebabkan orang dapat berbuat sesuatu untuk mencapai tujuan. Motivasi berawal dari pandangan bahwa manusiahanya melakukan pekerjaan yang menyenangkan untuk diselesaikannya. Pandangan ini memungkinkan terjadinya dalam keadaan terpaksa seseorang akan melakukan yang tidak disukainya. Manusia hanya mengambil obyek yang disukainya dan menjauhi obyek yang tidak menyenangkan, di mana manusia hanya melakukan sesuatu yang menguntungkannya. Menurut R. Hitt et al. (2001) ada tiga 
elemen utama didalam memahami motivasi, yaitu (1) keinginan yang kuat, (2) perilaku dan (3) pencapaian menuju ke arah tujuan. Karena itu motivasi dapat dikatakan sebagai keinginan, kebutuhan dan minat yang mendorong, mengaktifkan dan mengarahkan individu untuk berperilaku dalam upaya mencapai tujuan. Motivasi dapat berasal dari sumber-sumber internal dan eksternal, seperti kebutuhan fisiologis (makan, minum) adalah contoh sumber internal, sedangkan kebutuhan akan lingkungan sosial adalah contoh sumber eksternal, dan kadangkala motivasi merupakan interaksi dari faktor internal dan faktor eksternal.

Upaya untuk membentuk komitmen digambarkan sebagai usaha untuk membina hubungan yang berdurasi lama. Individu-individu yang memiliki komitmen organisasi memiliki peluang untuk tetap mempertahankan dirinya di organisasi lebih tinggi ketimbang individu-individu yang tidak memiliki komitmen. Mereka yang memiliki komitmen tinggi cenderung menunjukkan keterlibatan yang tinggi yang diwujudkan dalam bentuk sikap dan perilaku. Komitmen akan muncul jika adanya pemahaman nilai kerja, mengkomunikasikan nilai standar prestasi kerja dan menghubungkan dengan imbalan, mengambil tindakan evaluasi yang efektif, dan memberikan dukungan kerja kepada manajer dan supervisor.

Komitmen dalam penulisan ini diadaptasi dari Bashaw dan Grant (1994) yang berarti keinginan pegawai untuk tetap bertahan sebagai anggota di organisasi dan memiliki keinginan untuk melakukan usaha yang baik bagi pencapaian tujuan organisasi. Variabel ini diukur dengan indikator (1) kemauan pegawai; (2) kesetiaan pegawai; dan (3) kebanggaan pegawai .

Konsep tentang komitmen organisasi yang dinyatakan oleh Darmawan (2013) dimana memberikan tiga indikator untuk konsep komitmen. Hal ini memang sangat komprehensif sekali dimana (1) kemauan pegawai adalah suatu upaya niat baik pegawai untuk berinisiatif untuk menekuni bidang pekerjaannya; (2) kesetiaan pegawai adalah bentuk dari loyalitas pegawai untuk menampilkan identitas dirinya sebagai upaya untuk terlibat dan membantu organisasi mencapai tujuannya dimana pegawai bekerja; dan (3) kebanggan pegawai adalah bentuk dari adanya totalitas kerja atau hasil kerja yang maksimal untuk menunjukkan bahwa hasil kerjanya telah berhasil mencapai kualitas yang baik atau optimal. Ketiga hal tersebut merupakan indikasi bahwa seorang pegawai memiliki komitmen terhadap organisasi. Dari ketiga hal tersebut, maka dapat dilakukan pengukuran terhadap komitmen pegawai.

Budaya organisasi dapat terwujud dalam waktu yang relatif lama karena bersumber dan dapat dibentuk dari budaya internal, budaya eksternaldan budaya besar. Menurut Kast dan Rosenzweig (2007), budaya organisasi adalah seperangkat nilai atau norma, kepercayaan dan pemahaman yang penting yang dimiliki bersama oleh para anggotanya. Nilai-nilai atau gagasan dan kepercayaan secara bersama dianut oleh anggota itu seperti terwujud dalam lambang-lambang simbolis seperti mitos, upacara, cerita, legenda, dan bahasa khusus. Budaya organisasi terdiri dari batasan pedoman yang kuat yang bertujuan untuk membentuk perilaku. Budaya organisasi melaksanakan fungsi penting seperti; menunjukkan identitas diri untuk anggota organisasi, menompang komitmen untuk hal yang lebih besar dari pada diri sendiri, meningkatkan stabilitas sosial, dan menyediakan pokok pendapat yang dianut dan diterima untuk mengambil keputusan. Menurut Schein (2010) proses pembentukan budaya berhubungan erat dalam suatu ciri identik dengan proses dari pembentukan kelompok yang sangat penting dalam 'kelompoknya' atau ciri kelompok-pola-pola pembagian dari pemikiran, kepercayaan, perasaan dn nilai-nilai yang dihasilkan dari pembagian pengalaman dan secara bersama adalah apa yang dimaksud dengan hasil akhir budaya dari kelompok tersebut, tanpa adanya kelompok tidak akan ada budaya, dan tanpa adanya sedikit budaya kita hanya berbicara 
tentang kelompok orang, bukan "kelompok yang sebenarnya" sehingga pertumbuhan kelompok dan pembentukan budaya dapat dilihat dalam dua sisi dari mata uang yang sama dan keduanya berasal dari aktivitas kepemimpinan. Definisi tersebut menjelaskan bahwa budaya organisasi sebenarnya berkembang karena diciptakan dan ditumbuhkembangkan oleh individu yang bekerja di suatu organisasi, dan diterima sebagai nilai. Nilai tersebut digunakan sebagai pedoman bagi setiap anggota selama mereka berada di lingkungan organisasi dan dapat dianggap sebagai karakteristik khusus yang membedakan dengan organisasi lain.

Luthans et al. (2015) memberikan gambaran tentang karakteristik dari budaya organisasi, yaitu (1) aturan-aturan perilaku yang menjadikaan pedoman dalam hubungan antar anggota organisasi, komunikasi, terminologi, dan ritual; (2) norma, berupa aturan tertulis yang menuntun bagaiman cara bekerja; (3) nilai-nilai dominan, mengandung konsepsi yang jelas atau keyakinan tentang halhal yang diinginkan oleh anggota organisasi, seperti adanya konsepsi nilai mengenai kualitas, efisiensi yang baik, absensi yang rendah, dan sebagainya; (4) filosofi, berhubungan dengan kebijakan organisasi tentang cara memperlakukan anggota organisasi dan pihak-pihak yang berkepentingan lainnya; (5) peraturan, berisi petunjuk tentang pelaksanaan tugas dalam organisasi; (6) iklim organisasi, lingkungan fisik organisasi, perilaku hubungan antar organisasi, juga hubungan organisasi dengan pihak luar organisasi.

Berdasarkan hasil penelitian oleh Harris dalam Burstein (1987) mengindikasikan dimensi budaya organisasi untuk mengembangkan kualitas kehidupan kerja dan peningkatan produktifitas. Dimensi - dimensi tersebut adalah (1) otonomi tim kerja dan pengendalian atas ruang kerja; (2) partisipasi dan keterlibatan di organisasi; (3) orientasi pada komunikasi dan informasi; (4) hubungan informal dan sinergistik; (5) saling pengertian dan penghargaan kerja secara psikologis; (6) norma organisasi yang kreatif ; (7) orientasi pada teknologi; dan (8) orientasi pada penelitian dan pengembangan.

Kepuasan kerja di suatu pekerjaan tertentu berarti suatu bentuk kepuasan yang terbentuk saat menjalankan pekerjaan seperti memperoleh hasil kerja, perlakuan, dan disertai dengan suasana dari lingkungan kerja yang baik. Karyawan yang menikmati kepuasan kerja di pekerjaan ini akan lebih mendahulukan kewajiban dan tanggung jawabnya dari balas jasa, meski di sisi lain balas jasa itu menjadi hal yang utama. Adanya kepuasan kerja akan mempengaruhi aspek-aspek yang melingkupi kepuasan kerja itu sendiri. Steers (2005) menyatakan bahwa kepuasan kerja adalah emosi senang atau positif sebagai ungkapan pada penilaian terhadap pengalamannya dalam bekerja. Tingkat kepuasan kerja tersebut tergantung pada seberapa tingkat terpenuhinya kebutuhan fisik dan psikis bagi kelangsungan dan kesejahteraan hidupnya.

Luthans et al. (2015) menyatakan bahwa terdapat beberapa faktor yang mempengaruhi kepuasan kerja, yaitu (1) isi dari pekerjaan itu sendiri yang meliputi kemampuan pekerjaan, menyediakan tugas-tugas penting; (2) pembayaran sebagai cerminan bagaimana organisasi melihat kontribusi mereka terhadap organisasi; (3) promosi; (4) pengawasan berupa employee centeredness yang diukur dengan tingkat ketertarikan personal kepada karyawan yang ditunjukkan dengan memeriksa hasil-kerja bawahan, memberikan nasehat kepada bawahan, dan melakukan komunikasi yang baik; serta partisipasi yang mengijinkan bawahan untuk berpartisipasi untuk membuat keputusan yang 
mempengaruhi pekerjaan mereka; dan (5) suasana kerja seperti rekan sekerja, kerjasama yang erat maupun kondisi kerja yang mendukung seperti keadaan yang bersih, teratur, dan nyaman.

Penelitian ini akan mengkaji pengaruh motivasi kerja, komitmen organisasi dan budaya organisasi terhadap kepuasan kerja guru seperti yang digambarkan pada kerangka konseptual penelitian berikut ini.

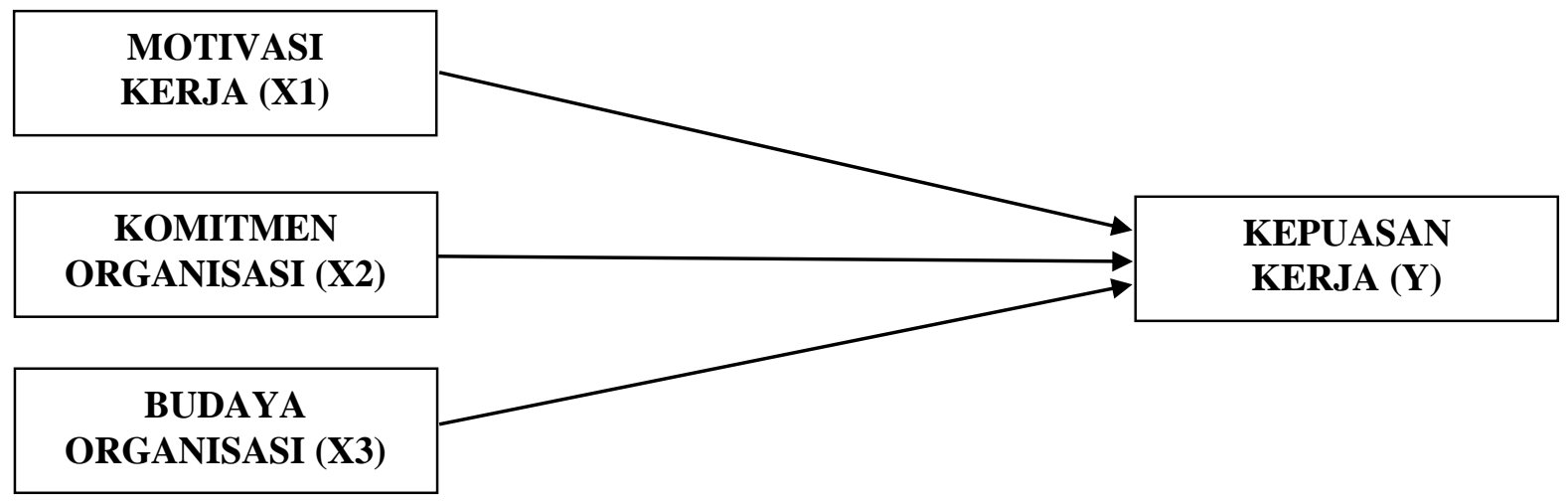

Gambar 1

Kerangka Konseptual

Hipotesis di penelitian ini ditetapkan sebagai berikut (1) variabel motivasi kerja mempunyai pengaruh yang nyata terhadap kepuasan kerja guru SD di Gugus Sekolah VI Kecamatan Kejayan Kabupaten Pasuruan; (2) variabel komitmen organisasi mempunyai pengaruh yang nyata terhadap kepuasan kerja guru SD di Gugus Sekolah VI Kecamatan Kejayan Kabupaten Pasuruan; dan (3) variabel budaya organisasi mempunyai pengaruh yang nyata terhadap kepuasan kerja guru SD di Gugus Sekolah VI Kecamatan Kejayan Kabupaten Pasuruan.

\section{METODE PENELITIAN}

Metode penelitian yang digunakan di penelitian ini adalah kuantitatif dengan metode survei, yaitu penelitian yang mengambil sampel dari suatu populasi dengan menggunakan kuesioner sebagai alat pengumpul data utama. Kuesioner adalah suatu bentuk pertanyaan yang dibagikan kepada responden untuk memperoleh jawaban terhadap pertanyaan tertentu. Teknik kuisioner adalah penyampaian adalah penyampaian daftar pertanyaan tertulis kepada responden dan diberi kesempatan untuk memperoleh respon atas pertanyaan yang diajukan guna memperoleh pengumpulan data primer. Subjek penelitian ini adalah 45 guru SD di Gugus Sekolah VI Kecamatan Kejayan Kabupaten Pasuruan. Teknik pengambilan sampel menggunakan accidential sampling. Teknik analisis menggunakan analisis linier berganda dengan tiga variabel bebas dan satu variabel terikat. 


\section{ANALISIS HASIL PENELITIAN DAN PEMBAHASAN}

Data yang terkumpul dari hasil kuesioner kemudian akan ditabulasi dengan perangkat lunak Statistical Package For Social Science (SPSS). Langkah awal adalah menguji validitas indikator dari masing-masing variabel. Instrumen yang digunakan di penelitian ini akan diuji melalui uji validitas seperti ditunjukkan pada Tabel 1 berikut ini.

Tabel 1

Uji Validitas Variabel

\begin{tabular}{|c|c|c|c|}
\hline Variabel & Item & Corrected item total correlation & Keterangan \\
\hline \multirow{6}{*}{$\begin{array}{c}\text { Motivasi } \\
\text { Kerja } \\
\text { (X1) }\end{array}$} & $\mathrm{X} 1.1$ & 0,4576 & Valid \\
\hline & $\mathrm{X} 1.2$ & 0,5739 & Valid \\
\hline & $\mathrm{X} 1.3$ & 0,4493 & Valid \\
\hline & $\mathrm{X} 1.4$ & 0,4452 & Valid \\
\hline & $\mathrm{X} 1.5$ & 0,4532 & Valid \\
\hline & $\mathrm{X} 1.6$ & 0,4818 & Valid \\
\hline \multirow{6}{*}{$\begin{array}{l}\text { Komitmen } \\
\text { Organisasi } \\
\quad \text { (X2) }\end{array}$} & $\mathrm{X} 2.1$ & 0,3721 & Valid \\
\hline & $\mathrm{X} 2.2$ & 0,3475 & Valid \\
\hline & $\mathrm{X} 2.3$ & 0,3384 & Valid \\
\hline & $\mathrm{X} 2.4$ & 0,4526 & Valid \\
\hline & $\mathrm{X} 2.5$ & 0,4425 & Valid \\
\hline & $\mathrm{X} 2.6$ & 0,4553 & Valid \\
\hline \multirow{6}{*}{$\begin{array}{c}\text { Budaya } \\
\text { Organisasi } \\
\text { (X3) }\end{array}$} & $\mathrm{X} 3.1$ & 0,3821 & Valid \\
\hline & $\mathrm{X} 3.2$ & 0,4365 & Valid \\
\hline & $\mathrm{X} 3.3$ & 0,6217 & Valid \\
\hline & $\mathrm{X} 3.4$ & 0,3855 & Valid \\
\hline & $\mathrm{X} 3.5$ & 0,3433 & Valid \\
\hline & $\mathrm{X} 3.6$ & 0,4761 & Valid \\
\hline \multirow{6}{*}{$\begin{array}{c}\text { Kepuasan } \\
\text { Kerja } \\
\text { (Y) }\end{array}$} & Y1 & 0,3319 & Valid \\
\hline & Y2 & 0,5262 & Valid \\
\hline & Y3 & 0,4334 & Valid \\
\hline & $\mathrm{Y} 4$ & 0,3654 & Valid \\
\hline & Y5 & 0,4429 & Valid \\
\hline & Y6 & 0,3347 & Valid \\
\hline
\end{tabular}

\section{Sumber hasil olahan SPSS}

Pada penelitian ini ditetapkan batas setiap item pertanyaan dinyatakan valid bila nilai corrected item total correlation lebih besar dari nilai 0,3. diketahui bahwa setiap item pernyataan dari berada di atas batas 0,3 . Hasil itu menunjukkan tidak ada pernyataan dari indikator yang dihapus dari yang tertera di kuesioner. Dengan demikian setiap item pertanyaan pada kuesioner dinyatakan valid.

Pengujian reliabilitas digunakan untuk menunjukkan sejauh mana alat pengukur dapat dipercaya. Instrumen dinyatakan reliabel bila dipergunakan beberapa kali untuk mengukur obyek yang sama akan menghasilkan data yang sama. Uji reliabilitas dilakukan dengan membandingkan nilai alpha dengan batas nilai 0,6. Bila nilai alpha berada di atas nilai 0,6 maka kuesioner dinyatakan reliabel. Berdasarkan Tabel 2diperoleh hasil uji reliabilitas dan semua variabel dinyatakan reliabel. 
Tabel 2

Uji Reliabilitas Variabel

\begin{tabular}{|c|c|c|}
\hline Item & Alpha & Keterangan \\
\hline $\mathrm{X} 1$ & 0,9862 & Reliabel \\
\hline $\mathrm{X} 2$ & 0,8451 & Reliabel \\
\hline $\mathrm{X} 3$ & 0,7893 & Reliabel \\
\hline $\mathrm{Y}$ & 0,8409 & Reliabel \\
\hline
\end{tabular}

\section{Sumber hasil olahan SPSS}

Uji asumsi klasik diawali dengan uji multikolinearitas. Keberadaan multikolinearitas dilihat dari nilai tolerance dan nilai VIF. Dari hasil olah data melalui SPSS diperoleh nilai tolerance dan VIF untuk variabel motivasi kerja $(0,734 ; 1,402)$, komitmen organisasi $(0,896 ; 1,332)$, dan budaya organisasi $(0,715 ; 1,011)$. Nilai tolerance yang didapatkan adalah kurang dari 1 dan nilai VIF antara 1 dan 2. Berdasarkan hal tersebut dapat dinyatakan persamaan model penelitian ini tidak menunjukkan gejala multikolinieritas. Variabel bebas tersebut tidak saling berkorelasi antara ada hubungan linier di antara variabel-variabel bebas dalam model regresi yang digunakan.

Pengujian autokorelasi untuk mengetahui sebuah model regresi linier ada korelasi antara kesalahan pengganggu pada periode $\mathrm{t}$ dengan kesalahan pada periode t-1 (sebelumnya). Jika dalam,suatu pengujian terjadi korelasi maka dinamakan ada problem autokorelasi. Pendeteksian Autokorelasi dapat dilakukan dengan menggunakan metode statistik dari Durbin-Watson. Dari hasil pengujian SPSS diketahui nilai DW sebesar 1,576. Hal ini berarti tidak terjadi autokorelasi.

Uji $\mathrm{F}$ digunakan untuk menguji pengaruh simultan dari variabel bebas terhadap variabel terikat Adapun hasil perhitungan dengan menggunakan software SPSS seperti pada Tabel 3berikut ini.

\begin{tabular}{|c|c|c|c|c|c|}
\hline \multicolumn{6}{|c|}{$\begin{array}{r}\text { Tabel } 3 \\
\text { ANOVA }^{\mathbf{b}} \\
\end{array}$} \\
\hline Model & $\begin{array}{l}\text { Sum of } \\
\text { Squares }\end{array}$ & Df & Mean Square & $\mathrm{F}$ & Sig. \\
\hline 1 Regression & 13.632 & 3 & 4.543 & 10.370 & $.000^{\mathrm{a}}$ \\
\hline Residual & 18.002 & 41 & .437 & & \\
\hline Total & 31.634 & 44 & & & \\
\hline
\end{tabular}

a. Predictors: (Constant), X3, X2, X1

b. Dependent Variable: $Y$

Sumber: Output SPSS

Berdasarkan hasil dari uji F ini dilakukan dengan membandingkan nilai Probability sig. dengan batas yang ditentukan yaitu 0,05 . Dari hasil perbandingan diperoleh nilai F hitung sebesar 10.370 dan nilai P Sig. pada Tabel 3 (ANOVA) diperoleh nilai 0,000 yang berarti berada di bawah batas 0,05 . Dengan demikian dapat dinyatakan bahwa pada taraf nyata $\alpha=0,05$, motivasi kerja, komitmen organisasi dan budaya organisasi mempunyai pengaruh yang signifikan secara simultan terhadap terhadap kepuasan kerja.

Uji t digunakan untuk menguji pengaruh parsial dari variabel bebas terhadap variabel terikat. Hasil perhitungan dengan menggunakan software SPSS diperoleh seperti pada Tabel 4 berikut ini. 
Tabel 4

Coefficients $^{\mathrm{a}}$

\begin{tabular}{|c|c|c|c|c|c|}
\hline \multirow[b]{2}{*}{ Model } & \multicolumn{2}{|c|}{$\begin{array}{c}\text { Unstandardized } \\
\text { Coefficients }\end{array}$} & \multirow{2}{*}{$\begin{array}{c}\begin{array}{c}\text { Standardized } \\
\text { Coefficients }\end{array} \\
\text { Beta }\end{array}$} & \multirow[b]{2}{*}{$\mathrm{t}$} & \multirow[b]{2}{*}{ Sig. } \\
\hline & B & Std. Error & & & \\
\hline (Constant) & 8.341 & 1.765 & & 1.911 & .059 \\
\hline $\mathrm{X} 1$ & .236 & .097 & .435 & 4.649 & .000 \\
\hline $\mathrm{X} 2$ & .265 & .102 & .226 & 2.270 & .025 \\
\hline $\mathrm{X} 3$ & .186 & .072 & .213 & 2.680 & .009 \\
\hline
\end{tabular}

a. Dependent Variable: Y

Sumber: Output SPSS

Berdasarkan hasil dari uji t ini dilakukan dengan membandingkan nilai Probability sig. setiap variabel bebas dengan batas yang ditentukan yaitu 0,05 . Dari hasil perbandingan diperoleh nilai $\mathrm{P}$ Sig. pada Tabel 4 diperoleh nilai 0,000 untuk variabel bebas motivasi kerja, nilai 0,025 untuk variabel bebas komitmen organisasi dan nilai 0,009 untuk variabel bebas budaya organisasi yang berarti berada di bawah batas 0,05 . Dengan demikian pada taraf nyata $\alpha=0,05$, masing-masing variabel bebas berpengaruh signifikan secara parsial terhadap terhadap variabel terikat.. Hal ini menunjukkan bahwa hipotesis penelitian ini terbukti benar. Persamaan regresi yang diperoleh adalah $\mathrm{Y}=8,341+0,236 \mathrm{X} 1+0,265 \mathrm{X} 2+0,186 \mathrm{X} 3$. Koefisien determinasi yang diperoleh seperti pada Tabel 5 .

Tabel 5

Model Summary

\begin{tabular}{|l|c|c|c|c|}
\hline Model & $\mathrm{R}$ & R Square & $\begin{array}{c}\text { Adjusted } \\
\text { R Square }\end{array}$ & $\begin{array}{c}\text { Std. Error of } \\
\text { The Estimate }\end{array}$ \\
\hline 1 & $.657^{\mathrm{a}}$ & .431 & .390 & .66260 \\
\hline
\end{tabular}

a. Predictors: (Constant), X3, X2, X1

Sumber: Output SPSS

Berdasarkan pada hasil penghitungan di Tabel 5, koefisien $\mathrm{R}$ sebesar 0,657 menunjukkan adanya pengaruh yang cukup kuat antara variabel bebas dengan variabel tidak bebas (terikat). Koefisien determinan sebesar 0,431 menunjukkan bahwa model regresi berganda ini yang variabel bebasnya terdiri dari motivasi kerja (X1) dan komitmen organisasi (X2) serta budaya organisasi (X3) telah memberikan kontribusi sebesar $43,1 \%$ terhadap pembentukan variabel terikat, yaitu kepuasan kerja guru. Sisanya sebesar 56,9\% ditentukan oleh faktor-faktor lain.

\section{PENUTUP}

Berdasarkan hasil analisis data, maka penelitian ini menetapkan beberapa kesimpulan sesuai dengan temuan yang diperoleh dan dibahas sebelumnya. Kesimpulan penelitian ini adalah (1) variabel motivasi kerja terbukti mempunyai pengaruh yang nyata terhadap kepuasan kerja guru SD di Gugus Sekolah VI Kecamatan Kejayan Kabupaten Pasuruan; (2) variabel komitmen organisasi terbukti mempunyai pengaruh yang nyata terhadap kepuasan kerja guru SD di Gugus Sekolah VI Kecamatan Kejayan Kabupaten Pasuruan; dan (3) variabel budaya organisasi terbukti mempunyai pengaruh yang nyata terhadap kepuasan kerja guru SD di Gugus Sekolah VI Kecamatan Kejayan Kabupaten Pasuruan. 
Dari hasil penelitian ini disarankan untuk meningkatkan kepuasan guru, maka masing-masing pihak sekolah harus mampu mendorong terciptanya motivasi kerja dan memperkuat komitmen organisasi berdasarkan pada budaya organisasi. Hal tersebut dapat dimulai melalui menciptakan lingkungan kerja yang kondusif, yaitu pihak sekolah dapat menyediakan segala sarana dan prasarana pendukung kelancaran proses belajar dan mengajar. Untuk mengembangkan kualitas sumber daya manusia, selain harus didukung oleh kepemimpinan yang baik dari kepala sekolah, juga harus didukung oleh kedisiplinan para guru. Untuk penelitian lebih lanjut dapat melibatkan variabel-variabel lain yang relevan dengan kehidupan di sekolah dan pengembangannya.

\section{DAFTAR PUSTAKA}

Burstein, Paul. 1999. "Social Movements and Public Policy." In How Social Movements Matter, edited by Marco Giugni, Doug McAdam, and Charles Tilly, 3-21. Minneapolis: University of Minnesota Press.

Bashaw, R., \& Grant, E. S. 1994. Exploring the Distinctive Nature of Work Commitments: Their Relationship with Personal Characteristics, Job Performance, and Propensity to Leave. Journal of Personal Selling and Sales Management, Vol. 14, pp.41 - 56

Darmawan, Didit. 2013. Prinsip-Prinsip Perilaku organisasi. Pena Semesta, Surabaya

Hitt, M.A., C.C. Miller, \& A. Colella. 2009. organizational Behavior: A Strategic Approach. Hoboken, NJ: Wiley \& Sons.

Kast, Fremont E, Rosenzweig, James E, 2007. Organisasi \& Manajemen, Jakarta: PT Bumi Aksara.

Luthans, F., Luthans, B. C., \& Luthans, K. W. 2015. Organizational Behavior: An Evidence-Based Approach. Charlotte: Information Age Publishing (IAP).

Schein, Edgar H. 2010. Organizational Culture and Leadership. 4th Edition. San Francisco: Jossey-Bass.

Steers, Richard M. 2005. Efektivitas Organisasi. (Terjemahan). Jakarta : Erlangga 